\title{
Implementasi VLAN dan Spanning Tree Protocol Menggunakan GNS 3 dan Pengujian Sistem Keamanannya
}

\author{
Wahyu Saputra $^{1 *}$, Fajar Suryawan ${ }^{2}$ \\ ${ }^{1}$ Program Studi Informatika \\ Universitas Muhammadiyah Surakarta \\ ${ }^{2}$ Program Studi Teknik Elektro \\ Universitas Muhammadiyah Surakarta \\ *wahyusaputra12@outlook.com
}

\begin{abstract}
Absstrak-Pada saat ini setiap perusahaan atau organisasi menggunakan jaringan komputer. Oleh karena itu maka perlu dibuat sebuah jaringan komputer dengan memiliki kinerja yang lebih baik. Dari hasil analisis, Virtual Local Area Network. (VLAN) merupakan sebuah konsep jaringan yang mampu memberikan hasil maksimal baik dari segi efisiensi perangkat, konfigurasi, dan keamanan jaringan yang digunakan. Selain itu, banyak perusahaan atau organisasi juga menerapkan konsep Spanning Tree Protocol. Penggunaan Spanning Tree Protocol adalah untuk mencegah terjadinya broadcast storm apabila sebuah perusahaan atau organisasi menerapkan sistem redundant pada perangkat jaringan digunakan. Meskipun telah memiliki tingkat keamanan yang baik namun masih perlu diuji dengan beberapa serangan dari pihak luar. Beberapa serangan yang mampu mengganggu jaringan $V L A N$ dan Spanning Tree Protocol adalah VLAN Hopping dan Spanning Tree Protocol Attack. Dalam penelitian ini dilakukan implementasi jaringan VLAN dan Spanning Tree Protocol menggunakan aplikasi GNS 3 serta pengujian sistem keamanan pada jaringan $V L A N$ dan Spanning Tree Protocol dari VLAN Hopping dan Spanning Tree Protocol Attack.
\end{abstract}

Kata Kunci: Spanning Tree Protocol, Spanning Tree Protocol Attack, VLAN, VLAN Hopping.

\section{Pendahuluan}

Perkembangan teknologi jaringan komputer pada saat ini telah tumbuh dengan pesat. Banyak perusahaan maupun organisasi yang memanfaatkan jaringan komputer untuk kegiatan operasional sehari-hari. Jaringan local area network ( $L A N)$ merupakan salah satu konsep yang banyak diterapkan berbagai perusahaan maupun organisasi. Pada dasarnya, jaringan LAN sudah cukup membantu bagi perusahaan atau organisasi dalam membantu kegiatan operasional sehari-hari. Namun seiring dengan berkembangnya kebutuhan jaringan komputer, maka ditemukan beberapa kelemahan dari jaringan LAN. Untuk mengatasi kelemahan tersebut, maka dilakukan pengembangan dari jaringan $L A N$ menjadi konsep jaringan virtual local area network (VLAN). Tambe (2015) mendefinisikan VLAN sebagai kumpulan beberapa workstation dalam $L A N$ yang mampu berkomunikasi satu sama lain pada $L A N$ yang sama dan saling terisolasi. Tulloh (2015) mendefinisikan VLAN (Virtual LAN) adalah sebuah teknologi yang dapat mengkonfigurasi jaringan logis independen dari struktur jaringan fisik. Selain definisi tersebut, Ali (2015) mendefinisikan bahwa VLAN merupakan sebuah LAN yang terkonfigurasi secara software bukan menggunakan kabel fisik. Prasetyo (2014) mengatakan bahwa VLAN dapat membagi jaringan berdasarkan subnet, hak akses, serta aplikasi yang digunakan oleh beberapa host di dalam satu perangkat switch yang sama. Lewis (2008) dalam bukunya yang berjudul LAN Switching and Wireless: CCNA Exploration Companion Guide mengatakan bahwa sebuah VLAN memungkinkan seorang administrator untuk menciptakan sekelompok peralatan yang secara logic dihubungkan satu sama lain. Dari beberapa pernyataan tersebut, penerapan konsep VLAN membuat jaringan switch dapat dibagi secara logic berdasarkan fungsi, departemen atau project sebuah tim. VLAN mampu mengurangi trafik jaringan dengan membentuk beberapa domain broadcast untuk memecah jaringan yang besar menjadi segmen-segmen independen yang lebih kecil sehingga pengiriman broadcast ke setiap perangkat jaringan secara keseluruhan menjadi lebih sedikit. Selain itu, konsep VLAN yang diterapkan memungkinkan sebuah jaringan menjadi lebih fleksibel sehingga tujuan bisnis yang diinginkan oleh perusahaan maupun organisasi dapat tercapai.

Implementasi konsep jaringan VLAN banyak menawarkan kelebihan bagi perusahaan maupun organisasi. Lewis (2008) menyebutkan bahwa jaringan $V L A N$ memiliki beberapa kelebihan yaitu dari aspek keamanan, jaringan VLAN dapat memberikan keuntungan apabila sebuah departemen yang memiliki data sensitif terpisah dari jaringan yang ada, maka akan mengurangi peluang pelanggaran akses ke informasi rahasia dan penting. Dari sisi penghematan biaya, jaringan $V L A N$ membuat biaya menjadi lebih hemat karena tidak diperlukannya biaya yang mahal untuk upgrade jaringan dan efisiensi penggunaan bandwidth dan uplink yang tersedia. Dari sisi performa, jaringan VLAN memberikan 
kinerja yang lebih tinggi, yaitu dengan membagi jaringan layer 2 menjadi beberapa workgroup secara logic (broadcast domain) serta mengurangi trafik yang tidak diperlukan pada jaringan sehingga dapat meningkatkan performa. Dari segi efisiensi dan 3 kemudahan, dengan menerapkan konsep jaringan $V L A N$ maka pengelolaan jaringan lebih mudah, karena user-user dengan kebutuhan jaringan yang sama berbagi $V L A N$ yang sama.

Banyak perusahaan atau organisasi memiliki jaringan yang cukup kompleks, selain memiliki jaringan VLAN yang sangat besar. Hal tersebut membuat perangkat jaringan terutama switch dapat digunakan semaksimal mungkin. Sistem redundant switch merupakan salah satu konsep yang dapat digunakan untuk mencegah terjadinya gangguan kegiatan operasional sebuah perusahaan atau organisasi apabila perangkat switch mengalami kerusakan. Efendi (2013) mengatakan bahwa redundancy merupakan langkah antisipasi terhadap suatu kegagalan dalam suatu proses aktivitas pengiriman data. Apabila sistem redundant diterapkan maka terjadinya loop dan broadcast storm data akan semakin besar. Oleh karena itu diperlukan Spanning Tree Protocol pada sebuah jaringan VLAN. Wiguna et al. (2013) mendefinisikan bahwa spanning tree protocol merupakan link manajemen protokol pada layer 2 yang menyediakan sistem jalur backup dan juga mencegah terjadinya loop dan broadcast storm yang tidak diinginkan pada jaringan yang memiliki beberapa jalur menuju ke satu tujuan dari suatu host.

Dari aspek keamanan, meskipun jaringan VLAN telah memiliki tingkat keamanan yang cukup baik namun masih perlu diuji dengan beberapa serangan dari pihak luar. Beberapa serangan yang mampu mengganggu adalah $V L A N$ hopping dan spanning tree protocol attack. Bajpai et al. (2016) mengatakan bahwa VLAN bopping bertujuan untuk membuat penyerang mendapatkan akses dari satu $V L A N$ ke $V L A N$ yang lainnya, sedangkan spanning tree protocol attack melibatkan seorang penyerang yang akan mengambil alih hak akses root bridge pada sebuah topologi. Vyncke et al. (2008) dalam bukunya yang berjudul LAN Switch Security: What Hackers Know about Your Switches mengatakan bahwa spanning tree protocol attack memiliki beberapa skenario serangan yaitu mengambil alih hak akses root bridge dan menimbulkan denial of service menggunakan pengiriman konfigurasi bridge protocol data unit (BPDU). Bajpai et al. (2016) mengatakan bahwa VLAN hopping memiliki beberapa skenario serangan yaitu double tagging attack. Serangan VLAN hopping dan spanning tree protocol attack dapat mengancam kerahasiaan data penting yang dimiliki oleh perusahaan. Supriyono et al. (2013) mengatakan bahwa data-data perusahaan adalah termasuk informasi rahasia yang harus dijaga.

Dalam penelitian ini dilakukan implementasi jaringan $V L A N$ dan spanning tree protocol menggunakan aplikasi GNS 3 serta menguji jaringan VLAN dan spanning tree protocol dari aspek sistem keamanannya. Tujuan utama dari penelitian ini adalah bagaimana perancangan jaringan $V L A N$ dan spanning tree protocol yang diimplementasikan menggunakan simulator jaringan GNS 3 serta bagaimana meningkatkan sistem keamanan dari jaringan $V L A N$ dan spanning tree protocol yaitu dengan cara mengambil tindakan mitigasi yang tepat dari jaringan $V L A N$ dan spanning tree protocol apabila terjadi serangan VLAN hopping maupun spanning tree protocol attack.

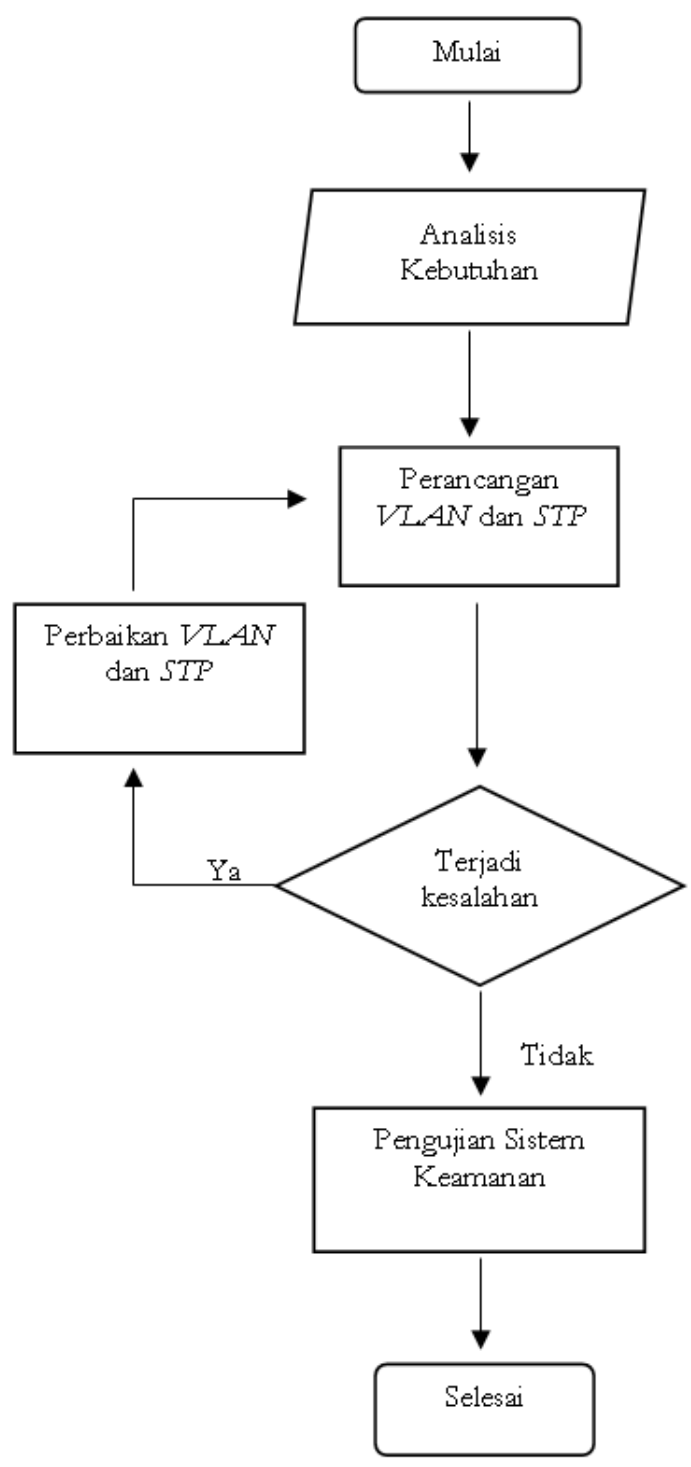

Gambar 1. Diagram alir penelitian.

\section{Metode}

Pada penelitian ini, untuk mengimplementasikan VLAN dan spanning tree protocol menggunakan aplikasi GNS 3 dan sebuah tool yaitu yersinia sebagai pengujian dari sistem keamanannya. Rancangan jaringan VLAN dan spanning tree protocol menggunakan contoh topologi dari sebagian gedung di Universitas Muhammadiyah Surakarta. Topologi jaringan VLAN dan spanning tree protocol yang dirancang akan dilakukan pengujian terhadap sistem keamanannya dengan beberapa serangan yaitu $V L A N$ bopping dan spanning tree protocol attack. Gambaran umum penelitian yang akan dilakukan dapat dilihat pada Gambar 1.

\subsection{Analisis Kebutuhan}

Pada tahapan ini dilakukan analisis terhadap alat maupun bahan yang dibutuhkan seperti spesifikasi hardware maupun software untuk mendukung penelitian. Spesifikasi hardware komputer yang dibutuhkan untuk mendukung penelitian ini yaitu: Processor Intel Core i3-2348M 2.30 GHz, RAM 4 GB DDR3, Harddisk 500 GB HDD dengan sistem 


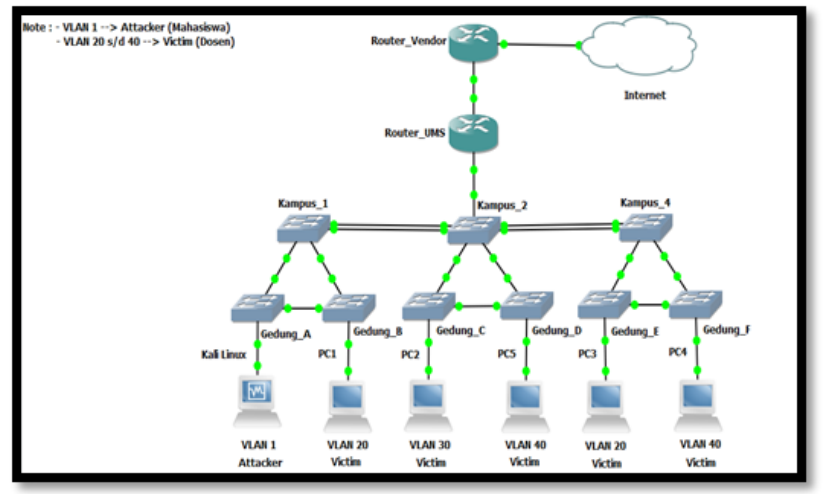

Gambar 2. Topologi virtual local area network ( $L L A N)$ dan spanning tree protocol

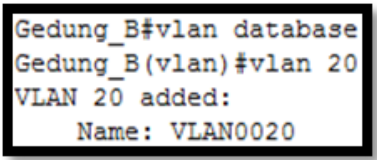

Gedung_B(config) $\#$ int fa $2 / 2$

Gedung $B$ (config-if) $¥$ switchport mode access

Gedung $B$ (config-if) $¥ 3$ witchport access vlan 20

Gedung_B(config) $¥$ int fa2/1

Gedung B(config-if) $¥ s w i t c h p o r t$ mode trunk

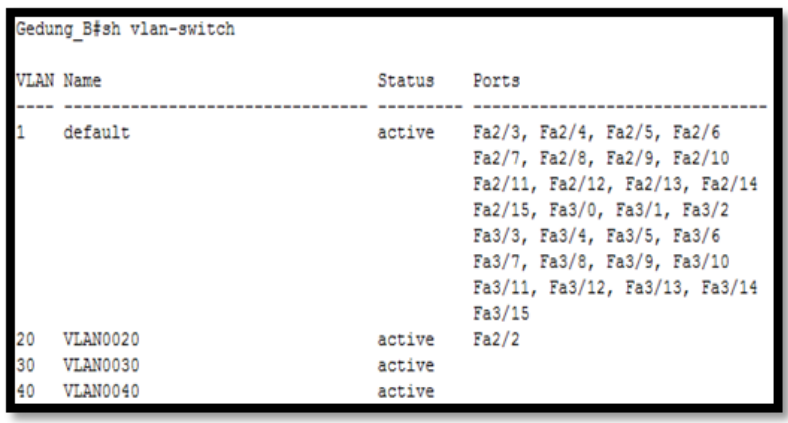

Gambar 3. Konfigurasi virtual local area network ( $L A A N)$

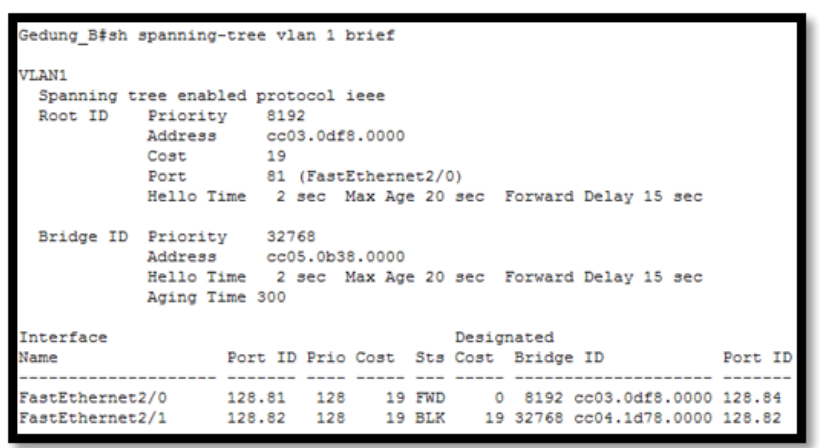

Gambar 4. Konfigurasi spanning tree protocol

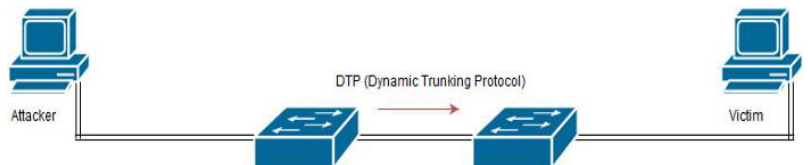

Gambar 5. VLAN bopping 
operasi yaitu Windows 10 (32 bit) pada hostcomputer dan keali linux (32 bit) pada guest virtual machine. Spesifikasi software yang digunakan untuk mendukung penelitian ini yaitu: Graphic Network. Simulator (GNS) 3, Virtual box, Yersinia, Wireshark.

\subsection{Perancangan Virtual Local Area Network (VLAN) dan Spanning Tree Protocol}

Pada tahapan ini, dilakukan perancangan topologi untuk jaringan VLAN dan spanning tree protocol serta konfigurasinnya di masing-masing perangkat. Topologi jaringan VLAN dan spanning tree protocol yang dirancang menggunakan contoh topologi sebagian gedung kampus di Universitas Muhammadiyah Surakarta. Gambaran topologi yang dirancang menggunakan GNS 3 dapat dilihat pada Gambar 2.

Dari Gambar 2 dapat dilihat bahwa ada 3 kampus di Universitas Muhammadiyah Surakarta yang digunakan sebagai topologi jaringan $V L A N$ dan spanning tree protocol. Setiap kampus masing-masing memiliki beberapa switch yang digunakan untuk mendistribusikan jaringan ke client dan terdapat backbone switch yang digunakan untuk menghubungkan jaringan antar kampus. Backbone switch yang terdapat di salah satu kampus juga digunakan untuk menghubungkan jaringan ke perangkat router utama di Universitas Muhammadiyah Surakarta yang nantinya akan terhubung ke jaringan internet. Konfigurasi VLAN dan spanning tree protocol dari topologi jaringan yang dirancang menggunakan GNS 3 adalah sebagai berikut :

a. Konfigurasi IP address

Proses awal dimulai dengan melakukan konfigurasi IP address di setiap perangkat jaringan. Jaringan yang menghubungkan antara router vendor dengan internet menggunakan network IP 192.168.100.0/24 dengan IP address 192.168.100.20/24 untuk router vendor. Koneksi antara router vendor dengan router UMS menggunakan network IP 192.168.1.0/24 dengan IP address 192.168.1.1/24 untuk router vendor dan IP address 192.168.1.2/24 untuk router UMS. Jaringan yang menghubungkan antara router UMS dengan client yang ada di setiap gedung kampus menggunakan network IP 192.168.10.0/24 dengan IP address 192.168.10.1/24 untuk router UMS dan IP address 192.168.10.2/24 192.168.10.7/24 untuk setiap client di kampus yang berbeda. IP address 192.168.10.1/24 digunakan sebagai gateway oleh client yang ada di setiap gedung kampus.

b. Konfigurasi Virtual Local Area Network (VLAN) Dalam topologi jaringan pada Gambar 2 terdapat perbedaan VLAN ID di setiap client yang bertujuan untuk mengisolasi jaringan di setiap unit kerja yang berbeda. VLAN ID yang digunakan dalam topologi jaringan pada Gambar 2 yaitu VLAN 1, VLAN 20, VLAN 30, VLAN 40. VLAN ID yang digunakan oleh mahasiswa berada di VLAN 1 sedangkan $V L A N 20$ sampai dengan VLAN 40 digunakan oleh para dosen. Untuk dapat saling bertukar informasi antar VLAN, setiap client menggunakan port yang terhubung ke switch. Setiap client hanya dapat mentransmisikan frame atau paket dalam 1 VLAN ID saja. Port yang menghubungkan antara client dengan switch menggunakan konfigurasi mode access. Setiap switch akan menerima frame atau paket VLAN ID dari port client kemudian akan mentransmisikan frame atau paket kembali ke $V L A N$ ID yang menjadi tujuan menggunakan port yang menghubungkan antar switch. Setiap switch dapat mentransmisikan frame atau paket dengan lebih dari 1 VLAN ID yang berbeda. Port yang menghubungkan antar switch menggunakan konfigurasi mode trunk. Konfigurasi virtual local area network (VLAN) dapat dilihat pada Gambar 3.

c. Konfigurasi Spanning Tree Protocol

Dari Gambar 2 dapat dilihat bahwa setiap switch memiliki beberapa jalur backup yang digunakan apabila salah satu koneksi jaringan terjadi kerusakan dapat menggunakan jalur koneksi yang lain agar jaringan masih dapat berjalan dengan normal. Penggunaan jalur yang digunakan sebagai backup dapat memperlambat kinerja sebuah jaringan dan akan mengakibatkan terjadinya loop dan broadcast storm, maka setiap switch menggunakan konsep spanning tree protocol untuk meminimalisir kerugian penggunaan jalur backup. Konsep spanning tree protocol akan mencegah terjadinya redundant link pada jaringan dengan menerapkan beberapa proses algoritma yaitu menentukan nilai bridge ID paling rendah, menentukan root path cost paling rendah, menentukan sender bridge ID paling rendah, dan menentukan port ID paling rendah. Dari penggunaan algoritma spanning tree protocol dapat menentukan pemilihan root bridge, root port untuk setiap non-root bridge, dan designated port dan non-designated port untuk setiap segmen network agar terjadi konvergensi. Dalam penelitian ini digunakan spanning tree protocol jenis per VLAN spanning tree protocol (PVST). Penggunaan PVST membuat spanning tree protocol dapat dikonfigurasi secara terpisah dan mengakibatkan perbedaan konfigurasi di masingmasing VLAN sehingga proses menuju konvergensi menjadi lebih cepat. Konfigurasi spanning tree protocol dapat dilihat pada Gambar 4.

\subsection{Pengujian Sistem Keamanan}

Pada tahapan ini, dilakukan pengujian sistem keamanan dari rancangan jaringan VLAN dan spanning tree protocol dengan menggunakan tool yaitu yersinia. Pada Gambar 2 dapat dilihat bahwa host dengan VLAN ID 1 akan menjadi attacker untuk melakukan serangan terhadap host dengan VLAN ID 20 sampai dengan VLAN ID 40 yang akan menjadi target serangan atau victim dengan asumsi bahwa attacker mempunyai hak akses untuk bergabung dalam jaringan VLAN dan spanning tree protocol yang telah dirancang. Skenario serangan yang digunakan untuk menguji sistem keamanan dari jaringan $V L A N$ dan spanning tree protocol yaitu:

a. VLAN hopping

b. Spanning tree protocol attack.

Skenario serangan pertama yang digunakan oleh $V L A N$ ID 1 adalah VLAN hopping. Skenario VLAN bopping merupakan jenis serangan yang dilakukan dengan cara mengambil hak akses dari satu VLAN ke VLAN lainnya. Metode yang dapat digunakan dalam skenario 
VLAN hopping yaitu double tagging attack. Metode double tagging attack merupakan metode serangan dalam VLAN hopping yang dilakukan dengan cara menanamkan tag 802.1Q encapsulation tambahan di dalam frame agar attacker dapat berkomunikasi dengan host yang menjadi target serangan. Skenario serangan VLAN bopping dapat dilihat pada Gambar 5.

Skenario serangan kedua yang digunakan oleh $V L A N$ ID 1 adalah spanning tree protocol attack. Skenario spanning tree protocol attack merupakan jenis serangan yang dilakukan dengan cara mengubah nilai bridge ID terendah pada sebuah switch agar attacker dapat mengambil hak akses menjadi root bridge. Metode yang digunakan dalam skenario spanning tree protocol attack ada 2 jenis yaitu taking over root bridge dan DoS using flood of config BPDU. Metode taking over root bridge merupakan sebuah metode serangan dalam spanning tree protocol attack yang dilakukan dengan cara mengambil hak akses root bridge dari switch yang memiliki nilai bridge ID terendah. Apabila serangan taking over root bridge berhasil dilakukan, maka seorang attacker akan menjadi root bridge dan dapat melihat beberapa variasi frame. Metode DoS using flood of config BPDU merupakan metode serangan spanning tree protocol attack selanjutnya yang dilakukan dengan cara mengirimkan konfigurasi BPDU per detik dengan jumlah yang besar sehingga penggunaan resource CPU pada switch akan menjadi lebih tinggi dan membuat sistem jaringan menjadi down. Skenario serangan spanning tree protocol attack dapat dilihat pada Gambar 6.

c. Pengujian Sistem Keamanan Virtual Local Area Network (VLAN)

Pada tahap ini dilakukan pengujian sistem keamanan $V L A N$ menggunakan metode serangan VLAN hopping yaitu double tagging attack. Dari Gambar 2 dapat dilihat bahwa host dengan VLAN ID 1 akan menjadi attacker untuk melakukan double tagging attack. Sebelum melakukan serangan double tagging, port attacker yang terhubung ke switch gedung A diasumsikan telah bergabung dalam jaringan VLAN dan spanning tree protocol dan memiliki hak akses untuk menjadi trunk port. Konfigurasi port attacker yang terhubung ke switch gedung A dapat dilihat pada Gambar 7.

Attacker akan melakukan double tagging attack dengan cara mengubah menanamkan tag 802.1Q encapsulation tambahan di dalam frame untuk diteruskan ke host yang akan menjadi target serangan menggunakan tool yaitu yersinia. Metode serangan yang digunakan attacker pada tool yersinia adalah sending $802.1 Q$ double encapsulation packet. Proses serangan double tagging dengan tool yersinia dapat dilihat pada Gambar 8.

Metode serangan sending 802.10 double encapsulation packet dari tool yersinia berhasil menanamkan tag 802.12 encapsulation tambahan di dalam frame yang dikirimkan menuju host target serangan sehingga attacker dapat berkomunikasi dengan host yang menjadi target serangan. Proses komunikasi yang berhasil dilakukan attacker dengan host yang memiliki VLAN ID yang berbeda dapat dilihat pada Gambar 9.
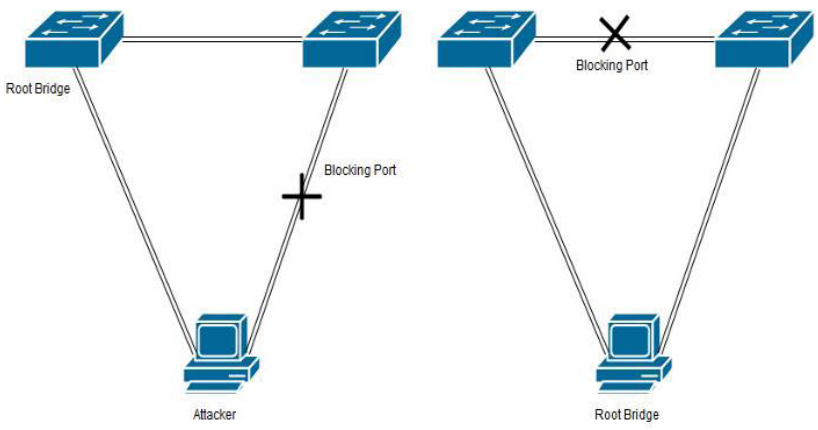

Gambar 6. Spanning tree protocol attack.

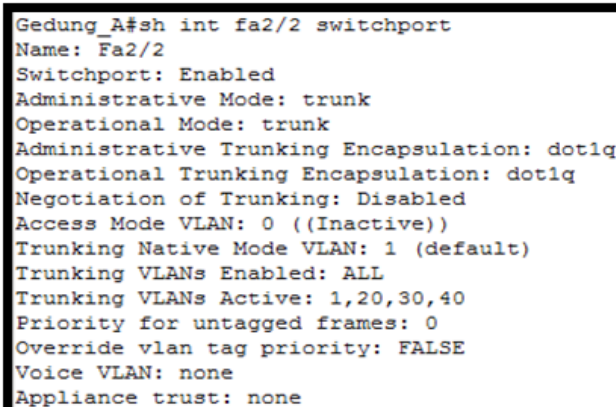

Gambar 7. Konfigurasi port attacker yang terhubung ke switch gedung A

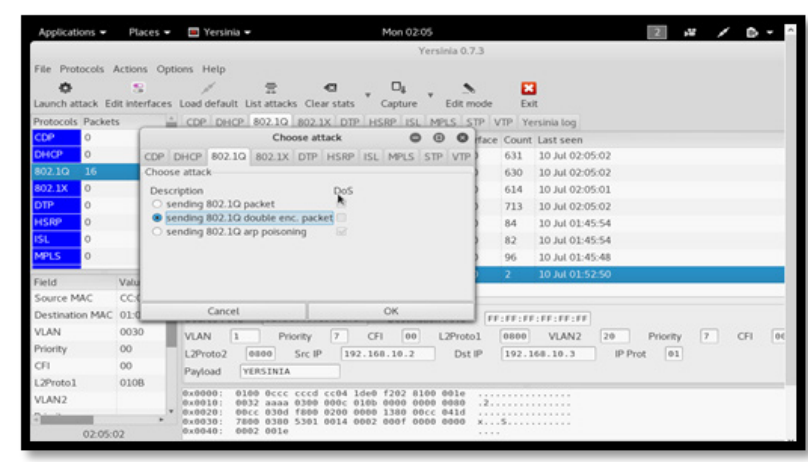

Gambar 8. Proses double tagging attack

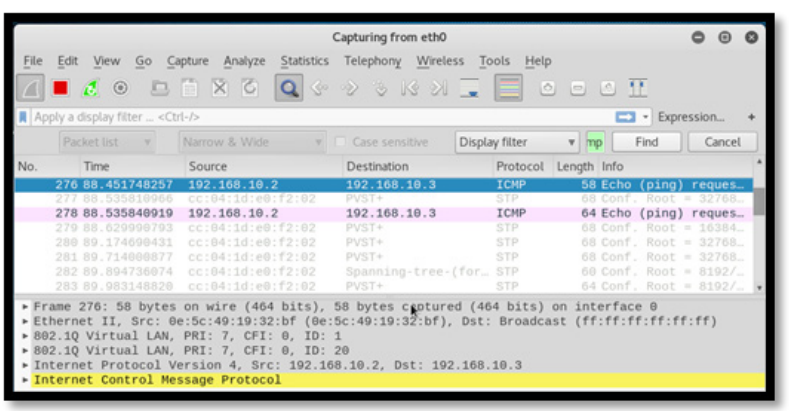

Gambar 9. Hasil capture double tagging attack di Wireshark

d. Pengujian Sistem Keamanan Spanning Tree Protocol

Tahap pertama untuk menguji sistem keamanan dari spanning tree protocol digunakan metode serangan spanning tree protocol attack yaitu taking over root bridge. Dari Gambar 2 dapat dilihat bahwa host dengan VLAN ID 1 akan menjadi attacker untuk melakukan taking over root bridge dengan asumsi bahwa attacker mempunyai hak akses untuk bergabung dalam jaringan $V L A N$ dan spanning tree 
protocol. Sebelum attacker melakukan taking over root bridge, backbone switch di kampus 1 UMS bertugas menjadi root bridge. Konfigurasi spanning tree protocol pada backbone switch di kampus 1 UMS dapat dilihat pada Gambar 10.

Pada saat backbone switch kampus 1 UMS menjadi root bridge, status salah satu port switch antara gedung A dan gedung B yang terhubung ke kampus 1 adalah blocking. Konfigurasi spanning tree protocol pada switch gedung A yang menghubungkan port attacker dapat dilihat pada Gambar 11.

Attacker akan melakukan taking over root bridge dari backbone switch kampus 1 UMS dengan menggunakan tool yaitu yersinia. Metode serangan yang digunakan attacker pada tool yersinia adalah claiming root role. Proses serangan taking over root bridge dengan tool yersinia dapat dilihat pada Gambar 12.

Metode serangan claiming root role dari tool yersinia berhasil mengambil hak akses root bridge dari backbone switch kampus 1 UMS dengan cara memperkecil nilai $M A C$ address sehingga terjadi konvergensi dan mengubah status attacker menjadi root bridge. Konfigurasi spanning tree protocol pada attacker setelah terjadi taking over root bridge dapat dilihat pada Gambar 13.

Pada tahap yang kedua dalam menguji sistem keamanan spanning tree protocol digunakan metode serangan spanning tree protocol attack yang lainnya yaitu DoS using flood config BPDU dengan asumsi bahwa attacker mempunyai hak akses untuk bergabung dalam jaringan VLAN dan spanning tree protocol. Sebelum attacker melakukan serangan DoS using flood config BPDU, tingkat penggunaan resource $C P U$ pada switch dan trafik penerimaan konfigurasi BPDU pada switch gedung A masih terlihat normal. Tingkat penggunaan resource $C P U$ pada switch dan trafik penerimaan konfigurasi BPDU pada switch gedung A dapat dilihat pada Gambar 14.

Attacker akan melakukan serangan menggunakan metode yang tersedia pada tool yersinia yaitu sending conf $B P D U$ s dengan tujuan meningkatkan penggunaan resource $C P U$ dan trafik penerimaan konfigurasi BPDU pada switch gedung A. Proses serangan DoS using flood config BPDU dengan tool yersinia dapat dilihat pada Gambar 15.

Metode serangan sending conf BPDUs dari tool yersinia berhasil meningkatkan penggunaan resource $C P U$ dan trafik penerimaan konfigurasi BPDU. Tingkat penggunaan resource $C P U$ pada switch dan trafik penerimaan konfigurasi $B P D U$ pada switch gedung A setelah terjadi DoS using flood config BPDU dapat dilihat pada Gambar 16.

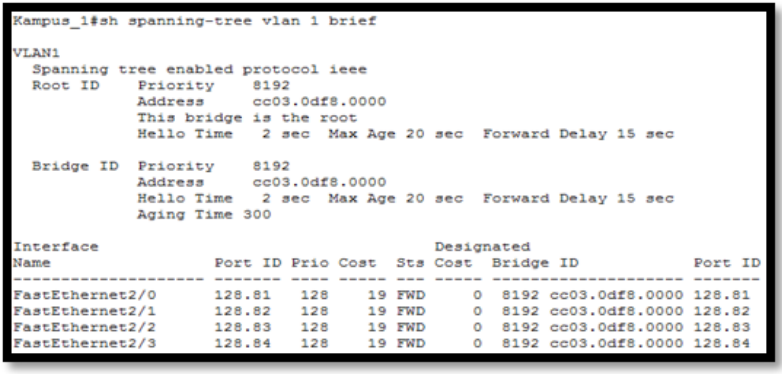

Gambar 10. Konfigurasi spanning tree protocol pada switch kampus 1 UMS

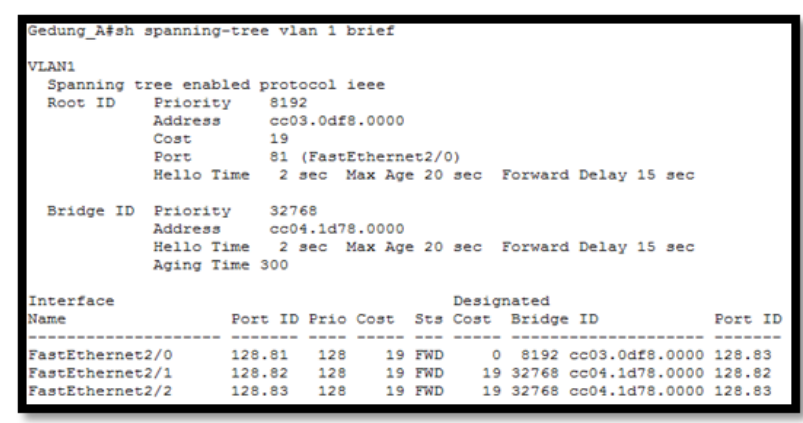

Gambar 11. Konfigurasi Spanning Tree Protocol pada switch gedung A

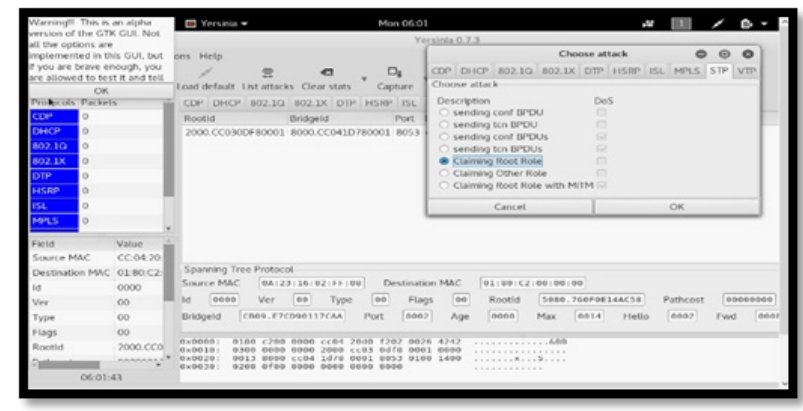

Gambar 12. Proses taking over root bridge

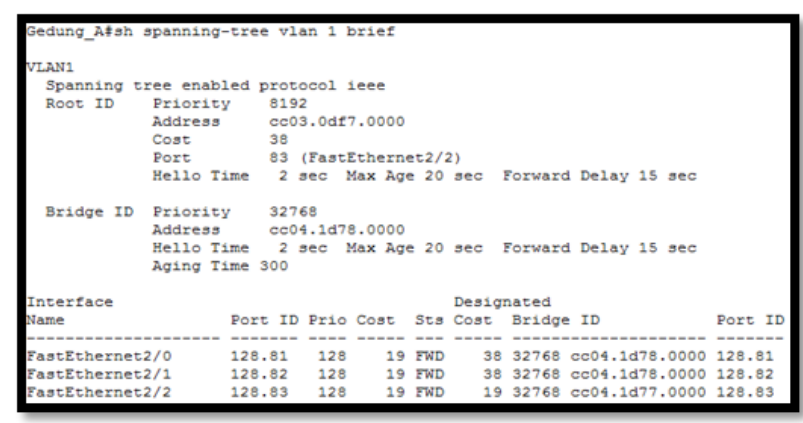

Gambar 13. Konfigurasi spanning tree protocol pada switch gedung A 
edung Ałsh proc cpu | incl sec

PO utilization for five seconds: $1 \xi / 0 \xi$; one minute: $1 \xi$; five minutes: 1

\section{Gedung A $\neq$ sh spanning-tree v1an 1 int fa2/2}

Port 83 (FastEthernet2/2) of VLAN1 is forwarding

Port path cost 19, Port priority 128, Port Identifier 128.83 .

Designated root has priority 8192 , address cc03.0df 7.0000

Designated bridge has priority 32768 , address cc04.1d77.0000

Designated port id is 128.83 , designated path cost 19

Timers: message age 3 , forward delay 0 , hold 0

Number of transitions to forwarding state: 1

BPDU: sent 7893 , received 179

Gambar 14. Tingkat penggunaan resource CPU dan trafik penerimaan konfigurasi $B P D U$

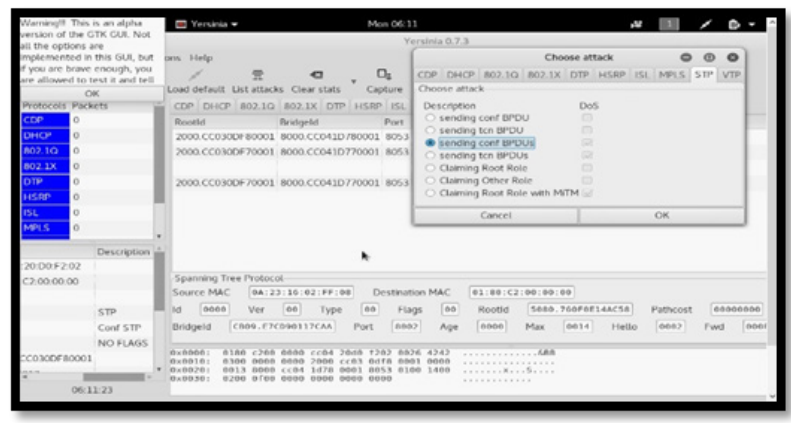

Gambar 15. Proses DoS using flood config BPDU

edung Ałsh proc cpu | incl second

CPO utilization for five seconds: 208/100\}; one minute: $10 \%$; five minutes:

edung_A $\$$ sh spanning-tree $v$ lan 1 int $f \mathrm{a} 2 / 2$

Port 83 (FastEthernet2/2) of VLAN1 is forwarding

Port path cost 19, Port priority 128, Port Identifier 128.83 .

Designated root has priority 1 , address 8 cda. $5 \mathrm{c} 71.1 \mathrm{ccd}$

Designated bridge has priority 32768 , address $\operatorname{cc} 04.1 \mathrm{~d} 78.000$

Designated port id is 128.83 , designated path cost 133 Hello is pending

Timers: message age 0 , forward delay 0 , hold 0

Number of transitions to forwarding state: 1

BPDU: gent 8079, received 21231

Gambar 16. Tingkat penggunaan resource $C P U$ dan trafik penerimaan konfigurasi $B P D U$

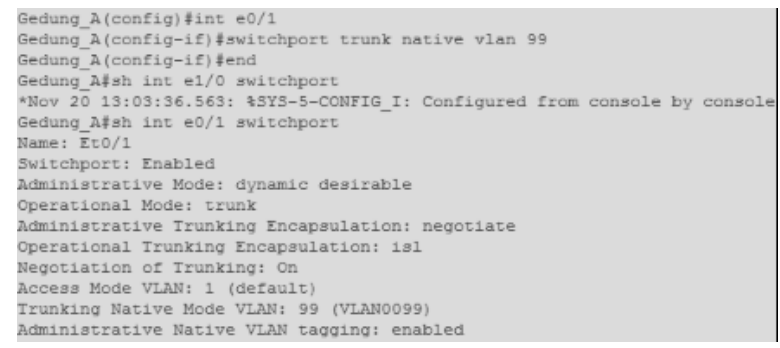

Gambar 17. Teknik mitigasi dengan tidak menggunakan native VLAN 1

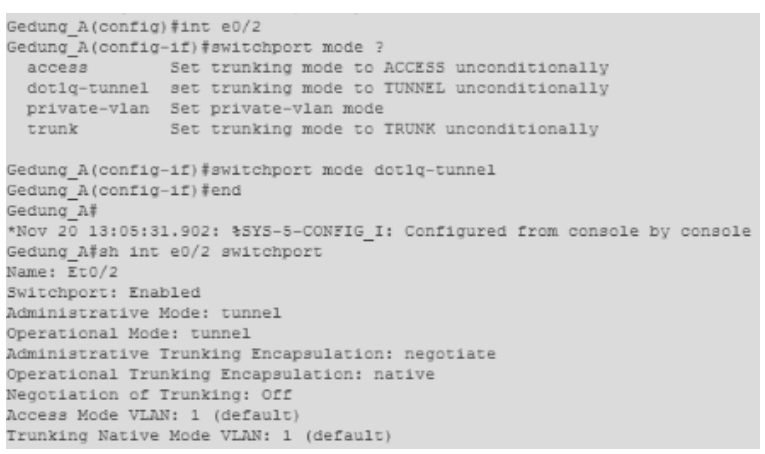

Gambar 18. Teknik mitigasi dengan tidak menggunakan switchport dynamic auto

\section{Hasil dan Pembahasan}

Dari hasil penelitian terdapat 2 topik utama yang dapat didiskusikan yaitu:

a. Hasil Implementasi VLAN dan Spanning Tree Protocol Menggunakan GNS 3

Berdasarkan hasil implementasi $V L A N$ dan spanning tree protocol menggunakan GNS 3 dapat dilihat bahwa konsep VLAN sangat efektif dalam mengisolasi jaringan sehingga mempermudah bagi administrator untuk melakukan pengelolaan jaringan yang bersifat kompleks. Dengan menggunakan konsep VLAN dapat mengurangi beban trafik jaringan sehingga performa jaringan menjadi semakin meningkat. Dari hasil implementasi juga menunjukkan bahwa konsep spanning tree protocol menyediakan jalur backup pada topologi yang berpotensi memiliki jalur redundant. Dengan menerapkan jalur backup, maka spanning tree protocol dapat mencegah terjadinya loop dan broadcast storm yang berakibat performa jaringan menjadi menurun.

b. Teknik Mitigasi Serangan VLAN Hopping dan Spanning Tree Protocol Attack

Berdasarkan hasil penelitian dapat diketahui bahwa konsep VLAN dan spanning treeprotocolmasih memiliki beberapa kelemahan dari aspek sistem keamanan. Namun, serangan VLAN hopping dan spanning tree protocol attack dapat diatasi dengan menggunakan beberapa teknik mitigasi.

c. Teknik mitigasi serangan VLAN hopping yaitu:

a) Tidak menggunakan native vlan 1.

Attacker dapat melakukan serangan VLAN hopping yaitu dengan memanfaatkan konfigurasi native VLAN dengan default nilai 1 pada port yang menghubungkan antar switch. Namun serangan VLAN hopping dapat diatasi dengan melakukan perubahan konfigurasi pada nilai native VLAN. Teknik mitigasi dengan tidak menggunakan native VLAN 1 dapat dilihat pada Gambar 17.

b) Tidak menggunakan mode switchport dynamic auto. Attacker dapat melakukan serangan VLAN hopping yaitu dengan memanfaatkan konfigurasi switch yang menggunakan mode switchport dynamic auto. Namun serangan VLAN bopping dapat diatasi dengan tidak menggunakan mode switchport dynamic auto dan melakukan perubahan konfigurasi mode switchport dari dynamic auto menjadi dot1q-tunnel. Teknik mitigasi dengan tidak menggunakan switchport dynamic auto dapat dilihat pada Gambar 18.

c) Menggunakan mode switchport access dan switchport nonegotiate.

Attacker tidak dapat melakukan serangan VLAN hopping apabila konfigurasi mode switchport pada switch menggunakan mode switchport access dan switchport nonegotiate. Teknik mitigasi dengan menggunakan mode switchport access dan switchport nonegotiate dapat dilihat pada Gambar 19. 


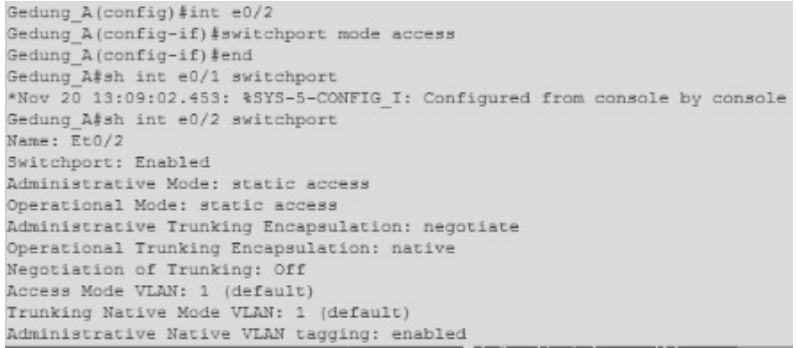

Gambar 19. Teknik mitigasi dengan menggunakan mode switchport access dan switchport nonegotiate

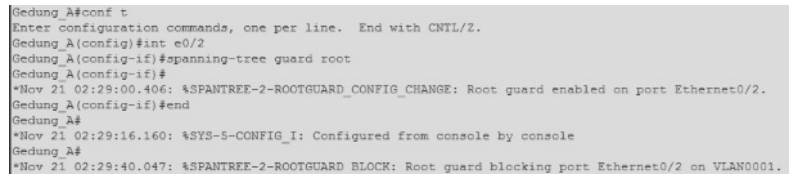

Gambar 20. Teknik mitigasi dengan menggunakan root guard

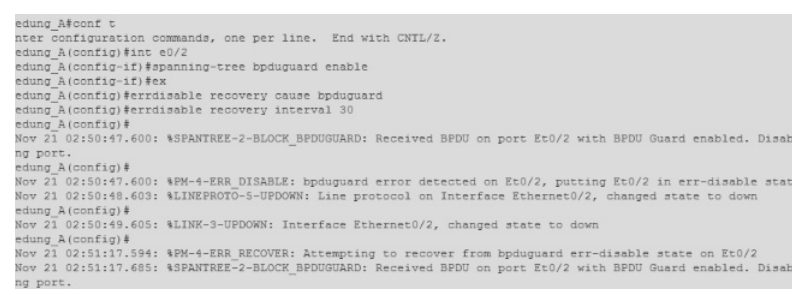

Gambar 21. Teknik mitigasi dengan menggunakan BPDU guard.

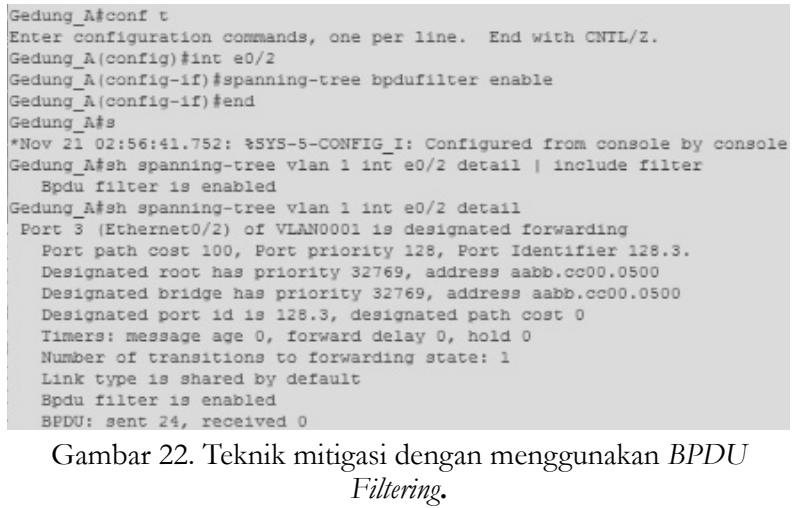

Gedung_Afcont $t$

Enter configuration commands, one per 11ne. End with CMIL/z. Eedung_A(config) fmls rate-1imit layer2 pdu 20020

Gambar 23. Teknik mitigasi dengan menggunakan layer 2 PDU rate limiter.

d. Teknik mitigasi serangan spanning tree protocol attack yaitu:

a) Root Guard

Root guard berfungsi untuk memproteksi switch lainnya yang ingin menjadi root yang baru dengan cara tidak mengaktifkan interface pada switch lainnya. Teknik mitigasi serangan spanning tree protocol attack menggunakan root guard dapat dilihat pada Gambar 20.

b) BPDU Guard

BPDU Guard berfungsi untuk memproteksi port yang telah aktif agar tidak terjadi pengiriman konfigurasi $b p d u$ yang baru. Teknik mitigasi serangan spanning tree protocol attack menggunakan bpdu guard dapat dilihat pada Gambar 21. d) BPDU Filtering

$B P D U$ filtering berfungsi untuk memproteksi port yang telah aktif agar tidak terjadi pengiriman maupun penerimaan konfigurasi $b p d u$ yang baru. Teknik mitigasi serangan spanning tree protocol attack menggunakan bpdu filtering dapat dilihat pada Gambar 22.

e) Layer 2 PDU Rate Limiter

Layer 2 PDU rate limiter berfungsi untuk membatasi jumlah paket pada layer $2 p d u$ protokol termasuk (BPDUs, DTP, Port Aggregation Protocol [PagP], CDP, STP, dan VTP paket) yang ditujukan untuk supervisor engine's processor pada CPU. Namun teknik mitigasi layer 2 pdu rate limiter hanya dapat digunakan untuk jenis switch catalyst 6500. Teknik mitigasi serangan spanning tree protocol attack menggunakan layer 2 pdu rate limiter dapat dilihat pada Gambar 23.

Untuk mengatasi serangan spanning tree protocol attack dengan metode taking over root bridge menggunakan teknik mitigasi root guard dan BPDU guard sedangkan metode serangan DoS using flood config BPDU dapat diatasi menggunakan teknik BPDU guard, BPDU filtering, dan layer 2 PDU rate limiter.

\section{Penutup}

Berdasarkan hasil penelitian yang dilakukan, menghasilkan beberapa kesimpulan yaitu implementasi VLAN dan spanning tree protocol yang dilakukan menggunakan GNS 3 menunjukkan bahwa konsep $V L A N$ dan spanning tree protocol sangat efektif digunakan apabila sebuah organisasi atau perusahaan memiliki topologi jaringan yang bersifat kompleks dan berpotensi mengalami redundant link.

Jaringan VLAN dan spanning tree protocol masih memiliki kelemahan dari segi aspek kemananan. Serangan yang dapat mengancam jaringan VLAN dan spanning tree protocol yaitu VLAN hopping dan spanning tree protocol attack. Namun serangan VLAN hopping dan spanning tree protocol attack mampu diatasi dengan menerapkan beberapa teknik mitigasi pada jaringan VLAN dan spanning tree protocol.

Setelah melakukan implementasi VLAN dan spanning tree protocol serta pengujian sistem keamanannya menggunakan aplikasi GNS 3 dan yersinia dapat diketahui bahwa penggunaan aplikasi GNS 3 dapat mempermudah untuk membuat desain perancangan jaringan dan lebih menggambarkan kondisi secara real dalam melakukan konfigurasi perangkat jaringan sedangkan aplikasi yersinia dapat digunakan untuk melakukan simulasi dan analisis serangan pada beberapa jenis protokol jaringan layer 2 .

\section{Daftar Pustaka}

[1] Ali, S.Y. (2015). Implementation of Virtual Local Area Network using Network Simulator, International Journal of Scientific Research Engineering \& Technology, 4(10), 1060-1065.

[2] Bajpai, A. \& Singh, I. (2016). Implementing Secured LAN Environment: Case Study, International Journal 
of Computer Science and Technology, 7(2), 41-51.

[3] Efendi, R. (2013). Percepatan Konvergensi dan Pencegahan Frame Loop Pada Virtual Local Area Network Dengan Memanfaatkan Rapid Spanning Tree Protocol, Jurnal Teknologi Informasi dan Komunikasi, 4(1), 45-51.

[4] Lewis, W. (2008). LAN Switching Wireless: CCNA Exploration Companion Guide, Cisco Press, Indianapolis.

[5] Prasetyo, E. (2014). Perancangan VLAN (Virtual Local Area Network) untuk Manajemen IP Address pada Politeknik Sekayu, Jurnal Teknik Informatika Politeknik Sekayu. 1(1), 10-23.

[6] Supriyono, H., Widjaya, J.A. \& Supardi, A. (2013). Penerapan Jaringan Virtual Private Network Untuk Keamanan Komunikasi Data Bagi PT. Mega Tirta
Alami, Jurnal WARTA, 16(2), 88-101.

[7] Tambe, S.S. (2015). Understanding Virtual Local Area Networks, International Journal of Engineering Trends and Technology, 25(4), 174-176.

[8] Tulloh, R., Negara, R.M. \& Hidayat, A.N. (2015). Simulasi Virtual Local Area Network (VLAN) Berbasis Software Defined Network (SDN) Menggunakan POX Controller, Jurnal Infotel, 7(2), 130-136.

[9] Vyncke, E. \& Paggen, C. (2007). LAN Switch Security: What Hackers Know About Your Switches, Cisco Press, Indianapolis.

[10] Wiguna, A.W., Herlawati \& Santoso, B. (2013). Penerapan Spanning Tree Protocol Terhadap Wide Area Network (WAN) Pada PT. Duta Lestari Sentratama Jakarta, Jurnal Techno Nusa Mandiri, 9(1), 